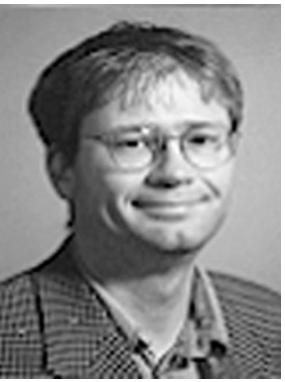

\title{
The strategic value of direct marketing: Expanding its role within the company, Paper 2
}

Received: 6th April, 2001

\section{Dr Alan Tapp}

is Senior Lecturer in Marketing at Bristol Business School. He has over 13 years' experience in commercial and academic marketing positions. He is the author of the best-selling text 'Principles of Direct and Database Marketing', and has over 20 publications in the fields of direct marketing, branding, charity marketing and, latterly, sports marketing. He has advised and trained companies as diverse as The Royal Mail and Coventry City Football Club. His major current interests are the strategic underpinnings of e-commerce and sports marketing.

Abstract This is the second of a series of three papers. The first paper of this series criticised the lack of foundation in much current thinking about the strategic role of direct and database marketing. This paper outlines an alternative direction for the industry based on a new model for the role of marketing. Experienced commentators in the field of marketing have argued that it is time for a major re-think of the role of marketing departments and of marketing itself. Both Doyle ${ }^{1}$ and Piercy $^{2}$ have commented on recent criticisms of marketing, arguing that while marketing is more important than ever, it is not being led by marketing departments. Rather, the delivery of customer value and customer satisfaction is the responsibility of operational divisions and customer service departments. In this paper, the author takes this framework and makes a case for a strategic role for customer database information as a way of facilitating the process of going to market. It is suggested that the current trend towards 'knowledge management' should be exploited by the database marketing profession to influence higher levels of corporate strategy.

\section{INTRODUCTION}

The theme of this paper is the proposal that database marketers are under-selling themselves internally within the organisation. In spite of all that has been said and written about the importance of market orientation, customer focus and the need to be close to customers, large firms find that in practice these things are still difficult to do. Of course much has improved, for instance companies use multifunctional teams to improve cooperation between departments. But even world-class companies continue to demonstrate the difficulties of staying market driven rather than listening to changing market needs. The current difficulties of Marks \& Spencer are a classic example: yet again a market leader, believing its position was unassailable, has been caught out by nimble competitors whose sense of what the market wanted was sharper.

This paper begins with a look at how marketing departments have fallen somewhat short in their role as guardians of the process of going to market. To address this, a different focus for the marketing function is proposed that moves away from managing the mix and towards a facilitating role within the company. The paper then looks at the 
implications of such a change for database and direct marketers.

\section{THE FALL AND RISE OF 'COMPANY-WIDE' MARKETING}

Marketing, or, more specifically, marketing departments, endured much criticism in the 1990s. ${ }^{3}$ As Doyle reported, a study by Coopers and Lybrand concluded that marketing is 'critically ill'.

A McKinsey report described marketing as having a 'mid-life crisis'. Doyle suggested that the symptoms of marketing's decline were down to:

- a decline in the market share and profitability of manufacturer brands

- a lack of genuine innovation from marketing departments, apart from line extensions

- marketers' loss of their primacy in shaping businesses, coming a poor second to such trends as JIT, TQM, business re-engineering and so on.

Doyle attributed this loss of primacy to marketers' tendency to isolate themselves in their own functional area, preferring to control tactical mix elements rather than attempt the more difficult and messy job of creating cross-functional teams that would deliver customer value and hence satisfaction. ${ }^{4}$

Piercy colourfully describes traditional marketing as 'dead in the water'. He says that the process of going to market is more important than marketing per se, and that going to market is a process owned by everyone in the organisation. ${ }^{5}$ The problem has been that while marketers have been fiddling about with superficial advertising campaigns, the reality of delivering superior value to customers has been driven by operations, research and development and customer service functions.

Arguably the most important thing for a company to concentrate on is the creation of sustainable competitive advantage. This may be defined as making an offer which the customer values, and which is demonstrably superior to competitors' offerings over time. The point is that whether this superiority is due to lower costs and hence lower prices, a higher rate of product innovation, superior customer service, or something else, the chances of marketing departments having much to do with it seemed small. Instead, marketing's idea of 'strategy' was superficial re-positioning and segmentations based on customers' willingness to pay rather than any genuinely different product/service need.

As Doyle, Piercy and Christopher ${ }^{6-8}$ and others have pointed out, these superficial positions have been undermined by new competitors who have fundamentally reconfigured value chains to reduce costs, add value or both. Examples include Direct Line which eliminated middlemen and hence removed a vast bank of costs. Meanwhile Toyota has cut down functional boundaries and focused on innovation, effective operational processes and customer support.

In a wide-ranging review of the links between marketing and competitive performance, Doyle and Wong hypothesised that successful businesses obtained competitive advantage by performing well in distinct areas. ${ }^{9}$ These were:

- market orientation

- strong supply chain systems and processes

- staff with high levels of capability, motivation, empowerment and strategic intent

- superior branding

- an effective network of relationships with customers, suppliers and other stakeholders 
- an emphasis on understanding and responding to change, learning about customers and spotting new market opportunities.

Doyle and Wong called for marketers to examine these elements and ask how they can best support their attainment. It is striking how many of Doyle and Wong's key factors are to do with employee attitudes. What can be suggested here then is that a modern marketing department has two strategic roles. The first is to stay close to and listen to customers, sensing market needs and market changes. The second is that as a result of this marketers should play a facilitating role, influencing other functions' decision making and processes so that customer satisfaction is at or near the top of their priorities.

\section{The role of database marketing}

These two strategic roles of a modern marketing department may perhaps provide database marketers with a great deal of food for thought. There is little focus at present by the direct/database industry on these issues, yet if Doyle and Wong, Piercy and the other commentators are right in their predictions, these are the business imperatives that database marketers must support if they want to be involved in strategic decision making. Doyle described the modern role for marketing departments as enabling marketing companywide, with the key drivers of customer satisfaction so often lying outside marketing's control. ${ }^{10}$ If this is accepted, it follows that the most powerful thing that database marketers can do is to find ways of helping other non-marketing departments to do their job of satisfying customers better. Figure 1 shows how.

Thus the database may facilitate operational processes (in particular through links with suppliers), service delivery, customer relationships and functions such as new product development and purchasing. A stronger link with marketing strategy could also be established.

Other authors have already discussed these links. DeTienne and Thompson took a 'company-wide' view of database marketing in linking it with the concept of the learning organisation. To quote them: 'the usefulness of DBM for organisational learning is partly in its iterative nature'.11 In other words, database marketers receive continual feedback from the market about the value the company is offering. This knowledge can feed upon itself and be recycled into the next test. It is felt here that such iterative learning could be expanded beyond tactical promotions to a wider environment within the firm.

The next step is to ask precisely how database marketers can help improve the key innovative, operational and service processes that add value for customers. The short answer is by using their knowledge of customers to influence decisions in these functions. Much of the rest of this paper is devoted to a closer look at how to achieve this.

To summarise so far, the case has been made for a new type of marketing department that sees its role as first understanding and staying close to customers and markets, and secondly as facilitating the internal job of getting to market, something that involves everyone in the company. The case has been made for database marketers to see their role in a more strategic light, with a primary function being that of helping the company with its market sensing. Expecting companies to act as well-oiled machines that will allow customer data to influence decisions in far-flung 


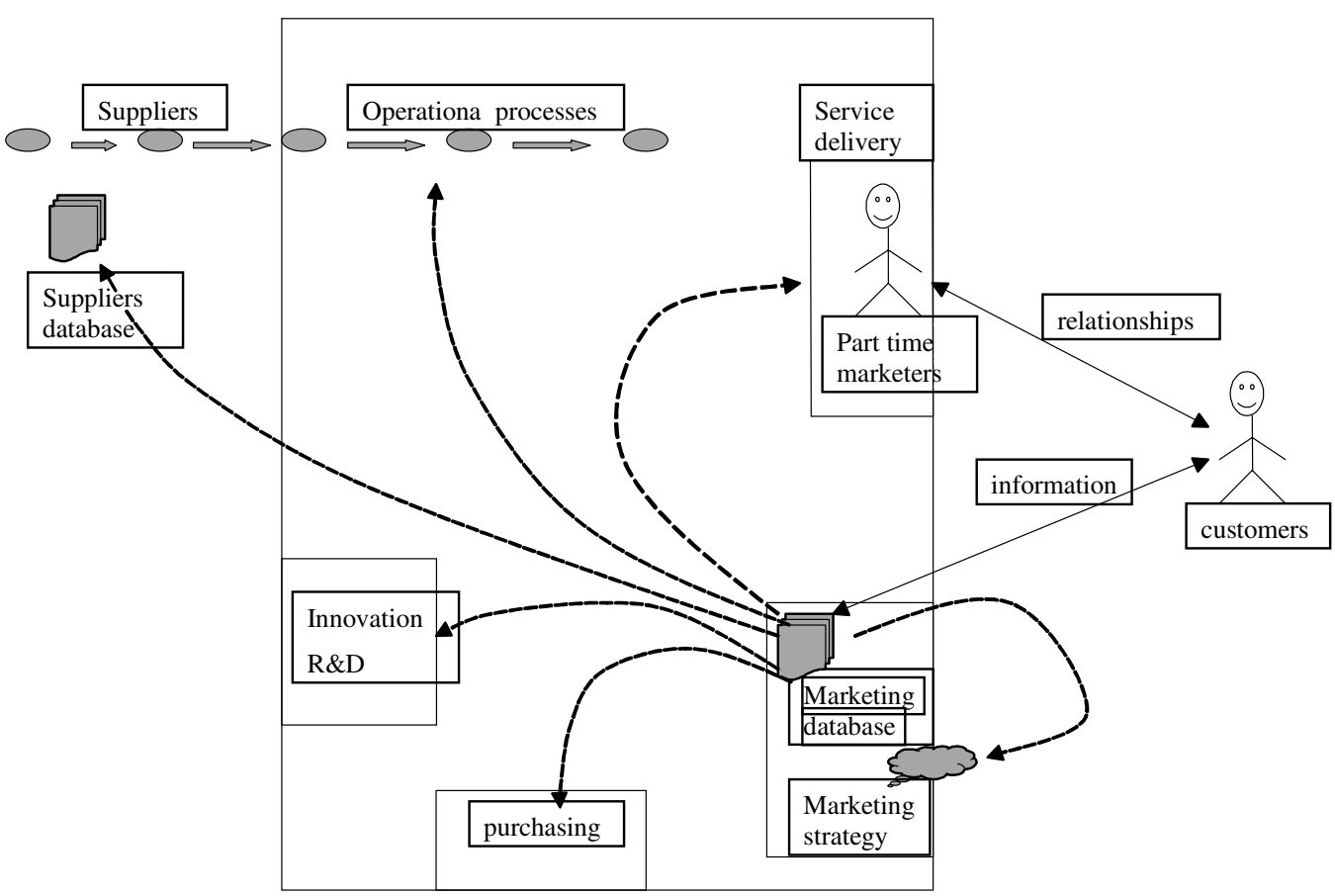

Figure 1 The links between DBM and other functional areas

departments is, however, naive. The next section examines what it is about market information that makes it so difficult to disseminate and use effectively.

\section{Making customer and market information come alive}

Piercy had some very interesting things to say about market information. He felt that what managers need is market sensing rather than market research. Managers need to understand rather than just record information. Piercy described market sensing as about how managers understand and react to the marketplace and the way it is changing. ${ }^{12}$ This can be taken further: market sensing is about holding a picture of the market which informs every decision made, and helps marketers influence the rest of the company.

Piercy goes on to attack what he regards as misplaced information- gathering objectives. For instance: the myth that more marketing information is needed. He criticises database marketers for their over-enthusiasm for a 'scientific' model of decision making based on massive data warehouses where marketers will 'know everything' about customers. More information does not necessarily mean better decisions. Secondly, the myth that marketers need information faster. 'Now we can get sales figures split by product type on our desks every hour'. As Piercy points out: so what? What do managers actually do with this information when they get it? The third myth is that marketers know what marketing information they want. Their ability to predict their needs accurately is low, especially as they move towards more important decisions about strategic direction. Piercy suggests that this scientific modelling process is muddied by the real world: fuzzy, unclear, qualitative and multiple goals, the inability to identify 
all options, lack of information availability and the impossibility of separating one decision from the rest.

According to Scarborough, Swan and Preston these issues can be understood by examining the nature of knowledge itself. Knowledge (among other things) is 'messy'; it travels via language not via data; it often slips away the more it is pinned down; it does not respond to rules and systems; and, quite frankly, the more loosely it is managed the better. ${ }^{13}$

Given the chaotic and jumbled nature of how most large companies and markets operate, the need for a clear picture of the market has never been greater. The question to consider is how database marketing information can be linked to this picture, accepting the 'messy' nature of knowledge, and getting away from the myth of a classical scientific decision-making process. There is a need for a good analyst to dig out the 'secrets' of the database, in particular what it tells about customers and how they relate to the organisation. The database analyst could then get together with an (open-minded) analyst from finance, and then similar analysts from purchasing, supply, production design, research and development and so on. They then need to get into the heart of it all — it is not going to be an automated process; it will be through people working together to create the knowledge and then to communicate it. This is not new, but it is about ways of working that recognise the need to bring knowledge 'alive' rather than relying on technology to do it.

It may be that the first thing to learn from Piercy's work is that database marketers need to do the hard work of extracting the secrets of the database themselves ie finding out what customers are telling about their habits, how they want the company to fit into their lives. Their next task is to simplify this 'story', before communicating it to colleagues in other functions. The final, and hardest, thing to do is to share direct and database marketing knowledge around the company in such a way that it is actually used. It is now clear that merely writing a report each month and copying it to departments does not work. There is plenty of academic evidence to support the view that the reality of 'market orientation' (using market information to direct the company's actions) is harder than the theory. Many studies have noted the low levels of market orientation in practice ${ }^{14,15}$ while studies examining why levels are so low have identified various barriers: departmentalisation, ${ }^{16}$ employee attitudes and beliefs, and systems, structures and processes. ${ }^{17}$

The conclusion then is that marketers need to take a more active role in making their knowledge useful. To see how, the paper now turns to the emerging disciplines of knowledge management and organisational learning. The remainder of the paper looks at how knowledge management and organisational learning theory may help with practical solutions to the problem of sharing knowledge.

\section{KNOWLEDGE MANAGEMENT AND ORGANISATIONAL LEARNING}

Readers of the first paper of this series might think that the author shows a bit of a nerve by, on the one hand, strongly criticising the over-use of jargon within the direct and database marketing industry and, on the other hand, bandying terms like 'knowledge management'. There is, however, something to be gained by looking to human resource management techniques, because what is being talked about here is how to better influence colleagues in other departments - something that marketers have not mastered if Doyle and Piercy are to be believed. 
First, some terms are explained. Bassi defined knowledge management (KM) as the process of creating, capturing and using knowledge to enhance business performance. ${ }^{18}$ Knowledge management grew out of the increasing concerns of companies who were undergoing 'business process re-engineering', ie cutting swathes of middle management layers out of their structures. These companies found (was this a surprise?) that when these middle managers left, they tended to take decades of vital 'know how' with them. Given that operational or market 'know how' often is the very thing that gives a company its competitive advantage, firms started to realise they were cutting their own throats. To avoid bleeding to death, some companies began the practice of recording and sharing knowledge around the company, often using enabling technology like Lotus Notes.

Management consultancies such as Ernst and Young and McKinseys have become strong advocates of what has become known as knowledge management techniques, and indeed use these techniques extensively themselves.

In the organisational learning (OL) literature there is a strong emphasis on creating the conditions in which individual and collective creativity may flourish, with the management of people - in particular culture, motivation and commitment — being at the core. ${ }^{19}$ Organisational learning is associated with key human resource management (HRM) issues such as training and development and empowerment 'in order to nurture new and expansive patterns of thinking..$^{20}$ In summary, OL is associated with HRM techniques, while the emphasis in KM has been the use of technology to facilitate knowledge sharing.

Both approaches have their strengths and weaknesses in helping database marketers. Knowledge management concentrates on the use of technology to help managers to maximise the use of knowledge held within the company. The assumption is that knowledge is an entity that can be shifted about and shared. To improve its usefulness, it is a matter of linking data and information to assemble higher levels of knowledge.

Certainly, this is how database marketers tend to view their discipline, and there is much merit in this.

Remembering Piercy's arguments about market sensing, however, the danger may be in seeing knowledge management as too scientific a process. Scarborough, Swan and Preston ${ }^{21}$ saw organisational knowledge as an everyday experience, embedded in the unwritten systems and cultures of the organisation. They gave the following warnings for those who believe managing knowledge is about using technology to record and share data:

- not all knowledge is codifiable, indeed most forms of 'higher knowledge' are arguably not codifiable

- just because the systems are there does not mean that non-marketing departments will be willing or interested in making them work ${ }^{22}$

- knowledge transfer relies on a shared system of meaning

- if too much focus is on technology, the danger is that the IT system may become a disabler of KM practice, creating a 'Tower of Babel' effect where too much complexity and too many data and too much information drive out shared understanding.

The third of these points is a reminder of the importance of marketers reaching out face-to-face with other functional areas, selling the importance of market focus rather than relying on it to sell itself. It is also a reminder of the need to 
communicate the message behind marketing data in ways that other departments can relate to - ie within their system of meaning. So marketers should talk to finance about the financial implications of their information, to purchasing about product trends, and so on.

Perhaps the best way to deal with this dichotomy is to split database-sourced knowledge into two types. Using work from McAdam and McCreedy, ${ }^{23}$ knowledge can be split into tacit and explicit types.

Tacit knowledge is non-verbalised, intuitive and unarticulated. Explicit knowledge is specified as being in writing, drawings or computer records. Clearly, knowledge held on marketing databases is explicit, while much of the knowledge held by database marketers themselves will be tacit. The tacit knowledge is often (though not always) the more valuable: 'experience with customers tells us that innovation $\mathrm{X}$ is likely to be more successful than Y'. This kind of knowledge is often held in such a way as to be most usefully brought out by the holder of that knowledge in a multifunctional team working on strategic projects - ie not buried on page 47 of yet another report. Meanwhile explicit knowledge can be dealt with in a more remote manner, perhaps through the much rehearsed argument of giving different functions access to the customer database via user-friendly front end software on their desks.

Finally, it is useful to remember that all too often information-sharing initiatives end in failure. Scarborough, Swan and Preston quote IBM's Larry Pruzak as saying that knowledge is both an asset (therefore it can be recorded, shared and so on) and a process of acting knowledgeably (using knowledge). ${ }^{24}$ It is the latter that many businesses find difficult. There are no quick fix ways to persuade people to act knowledgeably, but some suggestions were touched on earlier. At the heart of it lies a database marketer and a colleague from a different functional area, talking to each other until they understand each other's work, then seeing how they could help each other. The idea is to combine knowledge into a higher level of knowledge, without falling into the trap of over-managing the process. McAdam and McCreedy suggested that there is too much emphasis on types of knowledge (tacit, explicit, etc) and not enough attention paid to the social and technical processes through which knowledge combines and interacts. ${ }^{25}$

\section{CONCLUSION}

Database marketers have a vital role in helping combine their knowledge with that from other functions in order to solve complex problems, for example in a business undergoing change. This new role for database marketers, as facilitators, reflects the work of writers such as Gronroos, ${ }^{26}$ Gummersson, ${ }^{27}$ and Christopher, ${ }^{28}$ who argue that a marketer's role is to motivate the company to adopt a greater market focus. In this paper an attempt has been made to use some theory from knowledge management and organisational learning to help illuminate the path for database marketers to expand their influence. If this can be done then customer data may have finally arrived on the company strategic stage.

\section{References}

1 Doyle, P. (1995) 'Marketing in the new millenium', European Journal of Marketing, Vol. 29, No. 13, pp. 23-41.

2 Piercy, N. (1997) 'Market led strategic change', Butterworth Heinemann.

3 Doyle (1995) op. cit., for example, quotes Brady, J. 
and Davis, I. (1993) 'Marketing's mid life crisis', McKinsey Quarterly, No. 2, pp. 17-28.

4 Doyle (1995) op. cit.

5 Piercy (1997) op. cit.

6 Doyle (1995) op. cit.

7 Piercy (1997) op. cit.

8 Christopher, M. (1996) 'From brand values to customer value', Journal of Marketing Practice: Applied Marketing Science, Vol. 2, No. 1, pp. 55-66.

9 Doyle, P. and Wong, V. (1998) 'Marketing and competitive performance: An empirical study', European Journal of Marketing, Vol. 32, Iss. 5, pp. 514-535.

10 Doyle (1995) op. cit.

11 DeTienne, K. and Thompson, J. A. (1996) 'Database marketing and organisational learning theory: Toward a research agenda', Journal of Consumer Marketing, Vol. 13, No. 5, pp. 12-34.

12 Piercy (1997) op. cit.

13 Scarborough, H., Swan J. and Preston, J. (1999) 'Knowledge management and the learning organisation', Institute of Personnel and Development, London.

14 Greenley, G. and Matcham, A. S. (1986) 'Marketing orientation in the service of incoming tourism', Marketing Intelligence and Planning, Vol. 8, No. 2, pp. 35-39.

15 Hooley, G. J., Lynch, J. E. and Shepherd, J. (1990) 'The marketing concept: Putting theory into practice', European Journal of Marketing, Vol. 24, No. 9, pp. 7-23.

16 Wong, V., Saunders, J. and Doyle, P. (1989) 'The barriers to achieving stronger market orientation in British companies: An exploratory study', Proceedings of the 22nd Marketing Education Group Conference, pp. 35-64.

17 Harris, L. (1996) 'Cultural obstacles to market orientation', Journal of Marketing Practice: Applied Marketing Science, Vol. 2, Iss. 4, p. 14.

18 Bassi, L. J. (1997) 'Harnessing the power of intellectual capital', Training and Development, Vol. 51, No. 12, pp. 25-30.

19 Hall, D. T. and Parker, V. A. (1993) 'The role of workplace flexibility in managing diversity', Organisational Dynamics, Vol. 22, No. 1, pp. 5-18.

20 Senge, P. (1990) 'The fifth discipline: The art and practice of the learning organisation'.

21 Scarborough, Swan and Preston (1999) op. cit.

22 See in particular Scarborough, H. and Swann, J. (1999b) 'Case studies in knowledge management', Institute of Personnel and Development, Cromwell, Wilts.

23 McAdam, R. and McCreedy, S. (1999) 'A critical review of knowledge management models', The Learning Organisation, Vol. 6, No. 3.

24 Scarborough, Swan and Preston (1999) op. cit. 25 McAdam and McCreedy (1999) op. cit.

26 Gronroos, C. (1996) 'Relationship marketing: Strategic and tactical implications', Management Decision, Vol. 34, No. 3, p. 13.

27 Gummersson, E. (1991) 'Marketing orientation revisited: The crucial role of the part-time marketer', European Journal of Marketing, Vol. 25, No. 2, pp. 60-75.

28 Christopher (1996) op. cit. 